were landless, for there was little prospect of employ. ment and the alternatives were starvation or emigration. Thousands of emigrants found their way into the growing industrial towns of Great Britain and the United States of America.

The chapter on agriculture in this section is relatively short and might have been expanded with profit. That on trade is more exhaustive and includes a full discussion on mineral resources and industry; while the chapter on communications is a model of its kind.

Part 2 is a detailed regional analysis of the country. There are maps to show the distribution of demesne land and rough pasture ; and also population density. The latter are of special interest for they indicate that practically all the habitable part of the western seaboard had a density of population exceeding 400 per square mile. These regional studies are useful to anyone interested in specific parts of the country; but they also serve to show the wide difference that existed between, for example, the Provinces of Connaught and Leinster, and between the industrialized north-east and the remainder of the country where industry, though widely distributed, was of very little real significance.

The arrangement of this book gives rise, inevitably, to some repetition, and a few of the maps have suffered from over-reduction, but these are relatively minor points which do not obscure the fact that Mr. Freeman has made a substantial and lasting contribution to the historical geography of Ireland.

J. P. HAUGHTON

\section{ECONOMICS AND COMMON SENSE}

Economic Analysis

By Prof. Edmund Whittaker. Pp. xiii +460 . (New York: John Wiley and Sons, Inc.; London : Chapman and Hall, Ltd., 1956.) 52s. net.

DROF. E. WHITTAKER starts his consideration from the choices before individuals, farmers, businesses, voluntary groups and organs of government. This enables him to raise in his readers' minds the economic questions which may legitimately be asked. He sets out the quantities by which decisions should be guided and only introduces, as the argument proceeds, the terminology of the economist. $\mathrm{He}$ explains why, for example, a textile mill might be sold up while still a going concern; and points out that a proper policy for conservation is not always that one which guards the interest of the future by preventing too rapid an exploitation of natural resources in the present. It was perhaps not necessary to provide for the incompetence of the farmer who sows his seed so thickly that the crop does not ripen (pp. 224 and 225) ; and the reviewer, for one, would have liked to learn more of the reasons why, on p. 195, a family was supposed to value at 80 dollars the exhilarating experience of watching "the telly" for a month. But these objections are by the way. Prof. Whittaker asks questions and gives answers acceptable to most social scientists. His illustrations, however, are so peculiarly North American and drawn so often from farming that their significance may be lost on readers not well acquainted with the customs and constitution of the United States of America nor familiar with the techniques of agriculture. Surely, too, some more elegant way could have been found of expressing what was meant than by those inversions designed to avoid prepositions which so irritated at least one English reader. "Favorable purchase opportunities" on p. 203 is one example, and the reviewer would have been quite mystified by the "adjustment of land-labor proportionality called for by altered production and market conditions" on p. 218 had he not already known about the enclosures of common land in England during the eighteenth century.

An impressive mass of material is collected by departments of government in the United States, by agricultural stations, firms, universities and other research institutions. (The American economist is far better served in this than his British counterpart.) The hopes of the scientist for economics will be raised by this wealth of data. But they will certainly be dashed by the dependence of economic analysis (which the author does not attempt to disguise) upon the vulgar prejudices of common sense.

The book is designed, as the author tells us in his preface, to serve as a text for undergraduates taking the economic analysis and theory offered in Americen colleges after an introductory course. Prof. Whittaker insists that economic problems involve the interaction of more than those two variables to which most academic economists, faced with a class and a blackboard, have been content to confine themselves. But scientists will not gain much from the graphical representation of a three-variable analysis nor will they find in Prof. Whittaker's pages any detailed treatment of those fascinating issues upon which, without assistance from electronic computers and multi-channel analogue machines, six economists have so comfortably maintained thoir seven opinions. All these must be sought in the works which Prof. Whittaker has included in the bibliographies appended to his chapters.

Gilbert Walker

\section{MIDDLE-EASTERN APHIDOIDEA}

The Aphidoidea of the Middle East

By F. S. Bodenheimer and E. Swirski. Pp. iv +378 . (Jerusalem : The Weizmann Science Press of Israel, 1957.) n.p.

THE importance of aphids as economic pests and

as virus vectors has led to a considerable amount of research on this group in recent years and to a corresponding increase in the already large volume of aphid literature. This, however, is mostly in the form of specialist papers in a variety of journals, and up-to-date comprehensive works are comparatively few. A careful and well-documented study of the biology and systematics of the aphids of a geographical region such as the Middle East, which Prof. Bodenheimer and Dr. Swirski have produced, is therefore to be welcomed, particularly as the aphids of this area have never been studied intensively before.

The authors state at the outset that their aims are to help the taxonomist and the agricultural entomologist to identify aphids, and to suggest further lines of research into aphid ecology. The first half of the book deals with life-history studies, the problems of migration and host-finding, nutrition, climatic influences, and the relationships of aphids with ants and with predators, together with a brief chapter on aphid damage and control. In most of their eco- 